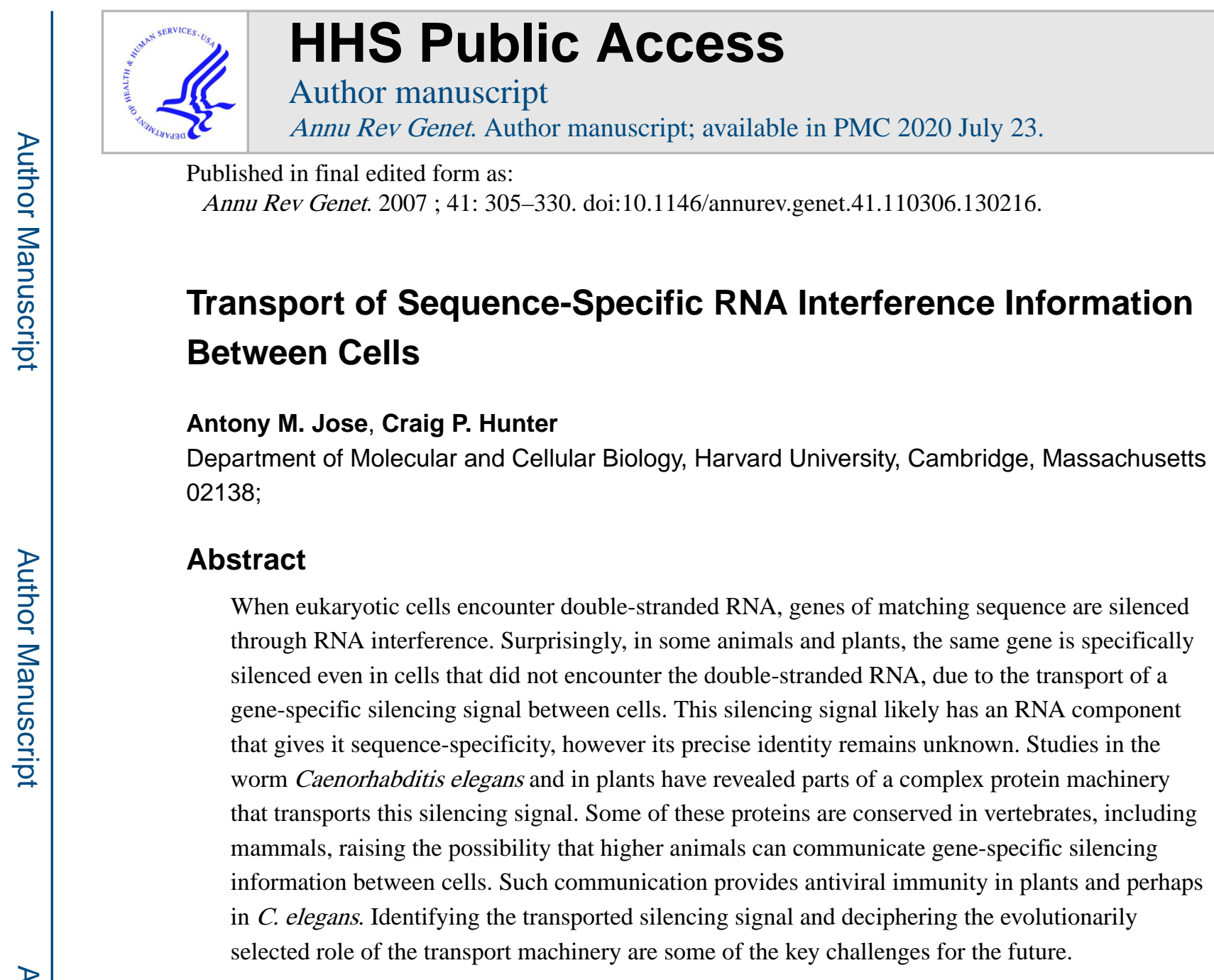

Keywords

gene silencing; dsRNA import; siRNA; systemic RNAi; endocytosis; epigenetics

\title{
INTRODUCTION
}

Cells communicate with each other to coordinate development and function in all multicellular organisms. Such communication often involves small molecules or proteins from a signaling cell being recognized by proteins in receiving cells. This recognition is then transduced in the receiving cell and activates specific signaling pathways to generate an appropriate response. Recent analysis of a gene silencing mechanism called RNA interference (RNAi) suggests that cells of a multicellular organism can also communicate with other cells by direct transport of regulatory RNAs.

An early indication that RNA could modulate cell function comes from the observation that double-stranded RNA (dsRNA) could trigger the inactivation of matching sequences through RNAi in the worm Caenorhabditis elegans (35). Such silencing was also soon discovered in

amjose@mcb.harvard.edu.

DISCLOSURE STATEMENT

The authors are not aware of any biases that might be perceived as affecting the objectivity of this review. 
plants (144), in trypanosomes (85), and in flies (56). Once dsRNA enters a cell, a member of the Dicer family of RNaseIII-like enzymes cleaves the dsRNA (12) to produce short interfering RNAs (siRNAs) of $\sim 21$ nucleotides $(32,45,155)$. These processed guide RNAs associate with a protein complex that generally includes a member of the Argonaute family of RNaseH-like enzymes to perform sequence-specific cleavage of RNA $(47,71)$.

Although first discovered as a response to experimentally delivered RNA triggers, we now know that key steps in RNAi underlie many diverse gene regulatory mechanisms. These include processes that (a) downregulate the expression of endogenous genes, $(b)$ direct transcriptional gene silencing and alter chromatin structure to promote kinetochore function and chromosome segregation (see chapter by K. Ekwall, this issue), and (c) direct elimination of DNA from somatic nuclei in Tetrahymena (150).

RNAi-like mechanisms called quelling in fungi (105) and posttranscriptional gene silencing in plants (136) reduce the expression of genes homologous to DNA introduced as transgenes. Curiously, such silencing in plants is noncell autonomous and can be transmitted between cells $(91,139)$. A similar spread of silencing between cells is also observed when dsRNA is injected into $C$. elegans to trigger RNAi (35). However, recent studies in $C$. elegans suggest that plants and animals use distinct mechanisms to transport silencing information between cells. Here, we review the noncell autonomous effects of RNAi and discuss some of the implications of this novel mode of intercellular signaling.

\section{IN C. ELEGANS}

\section{Transport of Silencing Information Between Cells}

RNAi (see Sidebar RNAi in C. elegans) can be triggered in $C$. elegans by injecting dsRNA into worms (35), soaking worms in dsRNA solutions (121), feeding worms bacteria that express dsRNA (127), and using transgenes that express dsRNA in vivo (124) (Figure 1). When worms take up dsRNA from the environment (presumably through the intestinal lumen), the target gene is silenced in both the intestinal cells and in a variety of tissues throughout the animal and its progeny $(121,127)$. Similar noncell autonomous silencing also occurs when dsRNA is injected into, or expressed in, a specific tissue $(35,146)$. These observations suggest that cells in $C$. elegans can transport either dsRNA or a derived silencing signal throughout the animal to cause sequence-specific silencing.

The transport of silencing information between cells may be a regulated process. RNAi triggered by transgenes that express $g f p$ hairpin RNA (dsRNA with a connecting loop at one end) in specific tissues leads to detectable transport of silencing information between cells when strong promoters are used to drive the transgene $(17,146)$. However, when $g f p$ hairpin RNA was expressed in the body-wall muscles using a relatively weak body-wall musclespecific promoter, GFP was visibly silenced only in body-wall muscle cells (128). Remarkably, introduction of unrelated dsRNA (with no sequences matching $g f p$ ) by injection or soaking led to GFP silencing in other tissues. Similar apparent induced transport and/or reception of a hairpin RNA-derived silencing signal was also reported when animals expressing hairpin RNAs were briefly starved (146). Such regulation in response to the environmental or physiological conditions suggests that the transport of sequence-specific 
silencing information is physiologically important. Notably, there are many sources of dsRNA in the genome of $C$. elegans (157), and endogenous siRNAs have been detected in vivo (5). However, it is currently unknown whether the silencing information from such endogenous RNAi is transported between cells.

\section{Import of Trigger dsRNA and Silencing Information}

To identify genes that control the import of dsRNA and the transport of silencing information between cells during RNAi, three independent genetic screens have been performed in $C$. elegans ( $s i d$ screen, fed screen, and $r s d$ screen) and one in Drosophila S2 cells. Analysis of the genes identified in these screens suggests that silencing signals are imported into cells using a dsRNA channel and specific endocytic machinery (Figure 2).

Sid screen.-Systemic RNAi-defective (sid) mutants were isolated as animals that cannot transport silencing information between cells. The intercellular transport of silencing information was followed by expressing GFP in both pharynx and body-wall muscles, and supplying $g f p$ dsRNA by expressing a transgene specifically in the pharynx while simultaneously feeding the worms bacteria that express $g f p$ dsRNA (146). Wild-type worms silenced GFP expression in the pharynx and due to the transport of silencing information from both the pharynx and the intestinal cells that take up the dsRNA from the food (systemic RNAi), they also silenced GFP in the body-wall muscles. In contrast, sid mutants continued to silence GFP in the pharynx due to autonomous RNAi, but no longer silenced GFP in the body-wall muscles because they lack the ability to transport the silencing information between cells. This screen identified at least five genes (146; C. P. Hunter, unpublished results), two of which, sid-1 and sid-2, have been analyzed in detail.

The sid-1 gene encodes a conserved protein with homologs in most animals including mammals (146), and in C. elegans the SID-1 protein functions as a dsRNA channel for the import of dsRNA and silencing information into most cells $(34,146)$. When dsRNA that targets a gene expressed in the germline was injected directly into the germline of sid-1 mutants, RNAi was triggered. However, the same dsRNA did not trigger RNAi when it was injected into the body cavity of sid-1 mutants, suggesting that sid-1 is required for the import of exogenously supplied dsRNA. Further, sid-1 mutant worms are also unable to import into body-wall muscles a silencing signal generated by expression of a $g f p$ hairpin RNA in the pharynx. The sid-1 gene is expressed in all non-neuronal cells and encodes a transmembrane protein that accumulates in peripheral cell membranes. Taken together, this suggests that the SID-1 protein may be a channel that imports both dsRNA from the environment and the silencing signal generated by transgenes that express hairpin RNA. To test this hypothesis, SID-1 was expressed in Drosophila cells, which lack both a SID-1 homolog and efficient mechanisms to take up dsRNA from the surrounding medium (34). In this heterologous system, SID-1 enables rapid import of dsRNA even under energy-depleted conditions, consistent with SID-1 acting as a passive dsRNA channel, rather than a pump or receptor. Further, SID-1 shows a strong preference for long dsRNA ( $\geq 100 \mathrm{bp}$ ) over short dsRNA or siRNAs. Thus, SID-1 likely enables the passive import of dsRNA into cells in which it is expressed. 
The finding that $s i d-1$ is not expressed in most neurons may explain why neurons are resistant to silencing triggered by exogenous dsRNA but are susceptible to RNAi triggered by providing dsRNA within neurons using transgene expression (124). However, RNAi does occur in neurons in response to exogenously supplied dsRNA in an enhanced $\underline{R} N A \underline{i}-1$ (eri-1) mutant where the efficiency of RNAi is increased due to the stabilization of siRNAs (55). In these experiments silencing in neurons was scored one generation after dsRNA exposure, thus the silencing signal may gain access into neurons not by transport but by inheritance through the germline. Alternatively, it is possible that a subthreshold level of the silencing signal may be successfully transported into neurons through a SID-1 independent mechanism or that there is undetected SID-1 expression in neurons. Although neurons of $C$. elegans are refractory to systemic RNAi, this is not a universal property of neurons as neurons of the parasitic nematode $G$. pallida are susceptible to exogenously supplied dsRNA (58).

The sid-2 gene encodes a single-pass transmembrane protein that is required for the import of dsRNA from the environment into the intestine (147). However, sid-2 is not required for the transport of a silencing signal from either injected dsRNA or endogenously supplied dsRNA. SID-2 is expressed in the intestine, where it localizes to the lumenal membrane. Based on localization and on the defects in animals that lack SID-2, SID-2 may modify SID-1 activity in gut cells to enable efficient dsRNA uptake from the environment. Alternatively, SID-2 may act to bring dsRNA into endocytic vesicles for SID-1-dependent transport into the cytoplasm. The ability to take up dsRNA from the environment is shared by some other Caenorhabditis species, but is notably less widespread among Caenorhabditis species than is the ability to transport a silencing signal between cells. $C$. briggsae lacks the ability to take up dsRNA from the environment, but transgenic expression of $C$. elegans SID-2 in $C$. briggsae is sufficient to confer sensitivity to environmentally supplied dsRNA. Conversely, the $C$. briggsae ortholog of SID-2 has a highly divergent extracellular domain and is unable to restore import of dsRNA in sid-2 mutant $C$. elegans. Additional experiments will likely reveal whether SID-2 transports dsRNA into the animal independent of SID-1 or whether SID-2 modifies the import of dsRNA through SID-1.

Fed screen.-Feeding defective ( $f e d$ ) mutants were identified as animals that are insensitive to RNAi triggered by feeding but are sensitive to RNAi triggered by injection (128). This screen was done in two steps. First, mutants were isolated based on their failure to exhibit RNAi when fed bacteria expressing dsRNA against a gene expressed in the germline. Second, the same dsRNA was then injected directly into the germline of the identified mutants and those that exhibited silencing were chosen for further analysis. Thus, fed mutants are defective in the transport of dsRNA-derived silencing information and not in cell-autonomous RNAi. This screen identified two genes (fed-1 and fed-2). Based on the similar phenotype and map position, the fed-1 mutant likely identifies the same gene as sid-2. The gene mutated in fed-2 is yet to be identified.

Rsd screen.-The $\underline{\text { RNAi }}$ ppreading defective ( $r s d$ ) mutants, like the fed mutants, were isolated as animals insensitive to RNAi triggered by feeding but susceptible to RNAi 
triggered by injection (126). This screen identified at least five genes ( $r s d-2,-3,-4,-6$, and $-8)$.

The $r s d-2, r s d-3$, and $r s d-6$ mutants are resistant to RNAi triggered by feeding dsRNA against germline genes but not to RNAi triggered by feeding dsRNA against somatic genes. Thus, these three genes appear to be required for the transport of silencing information into the germline but not into somatic tissues. Although RSD-2 has no detectable homologs in other organisms, it was found to interact with RSD-6, which contains a Tudor domain frequently found in RNA-binding proteins. RSD-3 has an epsin N-terminal homology (ENTH) domain that is often found in vesicle-trafficking proteins (67), and has a human homolog, Enthoprotin, that might also function in vesicle trafficking (143). Thus, endocytosis may play a role in the transport of silencing information into the germline. However, none of the $r s d$ mutants exhibit a generalized defect in endocytosis and mutants defective in endocytosis are not defective in the transport of silencing information into the germline (126). These observations suggest that RSD-3 may control vesicle trafficking in a pathway that is specific for the import of the silencing signal into the germline. Based on the similar phenotype and map position, $r$ sd-4 likely identifies sid-2/fed-1. The $r s d-8$ mutant identified the same gene as sid-1.

Drosophila screen.-Ten genes required for the endocytic uptake of dsRNA by cultured Drosophila cells have homologs in C. elegans that are required in C. elegans for RNAi triggered by feeding dsRNA (109; also see IN OTHER ANIMALS section). Four of these encode components of intracellular vesicle transport, two encode lipid-modifying enzymes, and four encode genes of unknown function. Worms were fed dsRNA targeting each of the above ten genes and tested four days later for their ability to perform RNAi against a test gene, unc-52, triggered by two days' supply of unc-52 dsRNA in the food. Silencing any one of these ten genes made worms resistant to RNAi. Although these results suggest that all ten genes are required for the import of dsRNA from the environment, additional experiments are required to determine if they are also required for other steps of silencing transport (Figure 2), such as the export of a silencing signal out of intestinal cells or the passage of dsRNA across the membrane.

The functions of genes identified in all four screens above suggest that the import of dsRNA or a silencing signal involves at least two steps: (a) endocytic uptake into the cell and (b) transport through a channel into the cytoplasm. Further analysis of the import genes identified thus far (Figure 2) and the identification of additional import genes will likely clarify our understanding of import mechanism(s) and may point to pathways that are shared with other intercellular transport mechanisms.

\section{What Is the Exported Silencing Signal?}

Although both short and long dsRNAs can trigger RNAi, only long dsRNAs ( $>50 \mathrm{bp}$ ) trigger the detectable transport of silencing information between cells in $C$. elegans (34). Injection of a 50-bp dsRNA targeting an essential germline gene causes embryonic lethality when injected into the germline. However, when injected into the intestine, the same $50 \mathrm{bp}$ dsRNA requires an additional $50 \mathrm{bp}$ of random dsRNA fused to it (for a total of 100-bp dsRNA) to 
cause embryonic lethality, suggesting that only long dsRNAs can efficiently initiate the transport of silencing information from intestinal cells to the germline where the target is expressed.

Processing the dsRNA into siRNA, a key step during RNAi, is not required for the transport of silencing information to other cells. When the intestines of rde-4 mutant animals (which do not process long dsRNA into siRNA) are injected with long dsRNA, RNAi is not observed in the injected animal but is observed in heterozygous progeny generated by mating the injected animals with wild-type males $(94,122)$. Furthermore, target mRNA is not required for the export of a silencing signal (40). Thus, the injected long dsRNA (or a RNAi-independent derived signal) is transported from the intestine into the germline.

During RNAi, RNA-dependent RNA Polymerases (RdRPs) can lead to the generation of dsRNA that includes sequences $5^{\prime}$ of the trigger dsRNA sequence, and these secondary dsRNAs can also act as or generate a transported silencing signal $(2,115)$. When an unc-22::gfp chimeric mRNA was strongly overexpressed in the intestine and GFP was targeted for RNAi by exposure only to $g f p$ dsRNA, an Unc-22 mutant phenotype was observed although unc-22 functions in body-wall muscles. This was apparently due to the generation of secondary dsRNA homologous to unc-22 in the intestine and the transport of this dsRNA or a derived silencing signal to body-wall muscles.

Further experiments to explore the substrate specificity of the dsRNA channel SID-1 and to characterize the structure of the transported silencing signal will help determine its identity.

\section{Inheritance of Silencing Information}

A single encounter with trigger dsRNA can lead to silencing that is inherited for many generations, although this effect is not fully penetrant (138). Several chromatin-remodeling factors are required for this long-term gene silencing, suggesting that the trans-generational inheritance of RNAi may be due to silencing at the transcriptional level, rather than posttranscriptional level. Consistent with this, the RNAi genes $r d e-1$ and $r d e-4$ are only required for the generation of the inherited signal upon initially encountering dsRNA, but not for the subsequent silencing directed by the signal in the next generation (40). Further, rde-1- and rde-4-independent cell-autonomous gene silencing can be triggered by injection of short antisense RNA (125). These considerations suggest that the inherited silencing signal may include secondary siRNAs, which are short and predominantly of antisense polarity (89). Curiously, secondary siRNAs are associated with argonaute-like proteins that lack conserved catalytic residues in the presumed nuclease site (152), suggesting that target cleavage is not important for their activity. Together, these observations indicate that inheritance of silencing information likely involves heterochromatinization in response to a signal that includes secondary siRNAs.

\section{IN OTHER ANIMALS}

In addition to $C$. elegans, many other animals can import silencing information into cells and initiate RNAi (Table 1). Clues to possible mechanisms for the import of dsRNA and, to a 
lesser extent, the spread of silencing information between cells are available for some of these organisms.

\section{Drosophila.}

RNAi screens in cultured Drosophila S2 cells, where dsRNA is provided in the growth media, are widely practiced and have been extremely productive (80). These RNAi screens have even been used to identify factors required for the import of dsRNA into these cells, identifying genes that apparently function in endocytosis, that encode scavenger receptors, and that encode lipid-modifying enzymes $(109,134)$. It is not clear whether any of these genes function, like sid-1, to transport dsRNA across the membrane. However, these genes likely mediate the triggering of RNAi in adult flies by intra-abdominal injection of dsRNA (31). Despite the ability to initiate RNAi in distant tissues by these injections, intercellular transport of silencing information apparently does not occur when RNAi is triggered by transgenes that express dsRNA (104). This might be because intercellular transport of a silencing signal in Drosophila is regulated by environmental or physiological conditions, just as in C. elegans and plants. Alternatively, in contrast to C. elegans and plants, Drosophila lack RdRPs, which can amplify silencing signals, and such amplification of small amounts of transported dsRNA may be required for efficient RNAi and/or for subsequent export of dsRNA (see section below).

\section{Mammals.}

Mice and cultured human cells can import siRNA or chemically modified siRNA silencing triggers $(87,118)$. When overexpressed in cultured human cells, the human ortholog of the dsRNA channel SID-1 improves the ability of those cells to import siRNAs (30). This observation suggests that mammals may also take up dsRNA through the SID-1 channel when physiological conditions activate or cause overexpression of the channel. Additionally, cholesterol-coupled siRNAs as well as antagomirs (single-stranded RNAs antisense to microRNAs, which control gene expression) with stabilizing modifications injected directly into the tail vein of mice trigger detectable silencing of the target in many tissues $(63,118)$. However, it is currently unknown whether cholesterol-coupled siRNAs enter mouse cells through either of the two mouse homologs of the dsRNA channel SID-1. Analysis of mice lacking SID-1 homologs will likely reveal the physiological role of SID-1 in mice and will also be an invaluable tool to dissect the role of mammalian SID-1 in the transport of trigger dsRNA, siRNA or other silencing signals.

In contrast to RNAi in C. elegans, RNAi in mammals is not typically triggered using long dsRNAs as they can cause a nonsequence-specific innate immune response, called the interferon response, that is associated with viral infections (110). However, some forms of long dsRNA are tolerated by the immune system and do not activate a strong interferon response $(103,119,131)$. Further, the potency of the interferon response induced by some long dsRNAs and siRNAs > 23 bp is cell-type dependent (100). However, in some cell types such as mouse embryonic stem cells, sequence-specific silencing using long dsRNA is possible $(13,88,149)$. These observations suggest that nonspecific and sequence-specific response pathways may be regulated and may coexist in mammals, as is the case in penaeid shrimp (102). 


\section{Can All Animals Transport Silencing Information Between Cells?}

The lack of $\underline{R} N A$-dependent $\underline{R} N A$ polymerases (RdRPs), which may amplify silencing, is often considered as evidence against the presence of a robust RNAi response and of intercellular transport of silencing information in some insects and vertebrates including mammals (104). However, recent studies suggest that in organisms that do not have an easily identifiable RdRP, DNA-directed RNA polymerases or other enzymes may perform a similar role (20). Both Drosophila and mice lack an identified RdRP, yet small RNAs called repeatassociated siRNA in the Drosophila germline (135) and piwi-interacting RNAs in mice (9, $38,42,65,143 \mathrm{a}$ ) accumulate in an asymmetric fashion that is reminiscent of synthesis by RdRPs. Furthermore, silencing of unpaired DNA during meiosis, a process that requires RdRP activity in both $C$. elegans (76) and in $N$. crassa (114), also occurs in mice (133). Notably, in $C$. elegans and in plants (see later section) the transport of a silencing signal does not require efficient RNAi. Therefore, in mammals and insects that lack RdRP-based signal amplification mechanisms, transport of silencing information between cells may occur even in the absence of robust cell-autonomous RNAi. Finally, the absence of observed systemic RNAi may reflect a requirement for specific environmental or physiological conditions. In C. elegans, intercellular spread of silencing information from body-wall muscles expressing gfp dsRNA is only detected upon induction by changes in the environment (128) and the extent of silencing in body-wall muscles in response to expression of dsRNA in pharyngeal cells is enhanced by starvation (146). In plants, similar physiological states can determine the extent of spread of silencing information (130).

\section{IN PLANTS}

\section{Transport of Silencing Information Between Cells}

The transport of silencing information between cells was first discovered in transgenic tobacco plants that spontaneously silenced both the transgene and the homologous endogenous gene $(90,92)$. In grafting experiments, the silenced state of rootstocks was transmitted to the grafted nonsilenced scions (91). Further, when a leaf of GFP-expressing tobacco plants was infiltrated with Agrobacterium cultures that carry a $g f p$ transgene, GFP expression was silenced throughout the plant (139). Silencing in these cases is likely triggered by improperly processed sense RNAs (aberrant RNAs) made from the transgenes that are converted by cellular RdRPs into dsRNAs (37). For example, silencing by senseonly transgenes required the RdRP RDR6 in Arabidopsis (26, 83). Accordingly, expression of hairpin dsRNA from inverted-repeat transgenes circumvents this requirement for RdRPs in tobacco plants (113). Finally, the transport of silencing can be triggered using either 2025nt RNAs purified from a silenced transgenic plant (49) or a single synthetic double-stranded siRNA (60), suggesting that the ultimate trigger for the transport of silencing information may be siRNAs in plants.

Plant cells transport silencing information to adjacent cells through intercellular pores called plasmodesmata and to distant cells through the vascular tissue called phloem (Figure 3). Most plant cells are connected with each other through dynamic pores called plasmodesmata (154), thus forming a cytoplasmic continuum. Mature guard cells that regulate gaseous exchange in the leaf are not part of the cytoplasmic continuum and consequently, transport 
of the silencing signal can cause silencing in guard cells only if the signal is received by immature guard cells that have not yet lost their plasmodesmatal connections $(50,141)$. Water and minerals are transported through xylem tubes, which are lined with dead cells, while photoassimilates, RNA, proteins, and silencing information are transported through phloem tubes, which are made of living enucleated sieve elements supported by companion cells. Transport through the phloem occurs from mature, photosynthetically autonomous organs (phloem sources) to new growth (phloem sink), and transport of silencing information over long distances also occurs from phloem source to phloem sink $(23,91$, 130, 141).

The physiological status and surrounding environment of a tissue dictates the extent of transport of silencing information. When silencing is initiated in single cells or small groups of cells, the movement of silencing information is restricted to about 10-15 cells in diameter in phloem source tissues such as mature leaves $(50,90)$. Conversely, in phloem sink tissues, such as new growth, silencing information progressively spreads from the phloem into the entire lamina of the leaves. Further, when mature leaves are converted into phloem sinks by shading, the transport of silencing information within the leaf becomes more extensive (130). Nutrient depletion may thus increase phloem flow bringing more silencing signals and nutrients to the leaf and/or may induce signal amplifiers such as RdRPs in the leaf.

\section{Cell-to-Cell Transport of Silencing Information}

Plant cells appear to use 21-nt siRNAs to transport silencing information through plasmodesmata. In the absence of amplification the spread of silencing is limited to $\sim 10-15$ neighboring cells (Figure 3), while more extensive spread of the silencing information can be achieved by a relay mechanism, whereby a silencing signal received by a cell in a leaf is amplified by the action of cellular RdRPs allowing additional cell-to-cell spreading within the leaf.

Limited cell-to-cell transport is observed when the endogenous gene SULPHUR is targeted for silencing by dsRNA expressed in phloem companion cells. Chlorosis (reduction in chlorophyll concentrations) due to RNAi of SULPHUR is observed in the companion cells and in the $\sim 10-15$ directly adjacent leaf cells. This limited spreading is unaltered in Arabidopsis mutants that lack the cellular RdRP, rdr6, suggesting signal amplification is not required $(29,50)$. In contrast, spreading is not observed in Dicer-like-4 (DCL4) mutants, which are deficient in the production of 21-nt siRNAs but not 24-nt siRNAs $(29,45)$. Furthermore, in an enhanced silencing mutant where the chlorosis spreads beyond 10-15 cells, thelevels of 21-nt siRNA are increased (29). Thus, the RNA component of the silencing signal transported through plasmodesmata is likely $21-n t$ siRNAs.

Additionally, mutants specifically defective in the transport of a silencing signal would be expected to lose the ability to spread chlorosis without losing the ability to generate 21-nt siRNAs. Screens for such silencing movement defective mutants (29) identified SMD1, $S M D 2$, and SMD3 mutants, and the genes mutated in SMD mutants are currently unknown.

In contrast to the limited transport associated with silencing of endogenous genes, silencing of transgenes often spreads throughout the leaf lamina (presumably due to relay signal 
amplification). For example, expressing dsRNA matching the $5^{\prime}$ region of $g f p$ in phloem companion cells caused uniform silencing of GFP in the entire leaf of transgenic Arabidopsis plants (50). However, in mutants lacking the cellular RdRP rdr6, GFP silencing (like silencing of endogenous genes) could be detected only in 10-15 cells adjacent to the veins. This indicates that RdRP activity is required for long-range spread of silencing. Similar experiments implicate the putative RNA helicase SDE3 in the spread of silencing information. In these experiments, wild-type plants as well as $r d r 6$ and $s d e 3$ mutant plants accumulated similar amounts of 21-nt and 24-nt siRNA matching the $5^{\prime}$ region of $g f p$ that corresponds to the trigger dsRNA, as is typical for plants undergoing transgene-triggered RNAi $(45,46)$. However, siRNAs corresponding to the $3^{\prime}$ region of $g f p$ (outside sequences matching trigger dsRNA) were exclusively 21 -nt long and more of these 21-nt siRNAs accumulated in wild-type plants than in $s d e-3$ or in $r d r-6$ mutants (50).

These results suggest a model (Figure 3) whereby long dsRNA is processed into 21-nt siRNAs by DCL4 during silencing. The movement of these 21-nt siRNAs through plasmodesmata is dependent on the silencing movement defective genes SMD1, 2, 3. This results in the spread of silencing to $~ 10-15$ neighboring cells. RDR6 and SDE-3 in these neighboring cells amplify the signal, producing secondary dsRNA beyond the original trigger. These cells then process the secondary dsRNA and relay the silencing information further by spreading the 21-nt siRNAs. The extent of spread depends upon the physiological state of the tissue and this regulation may occur through modulation of RDR6 and SDE3 activity.

\section{Long-Distance Transport of Silencing Information}

Plants can also transport silencing information over long distances $(\sim 20 \mathrm{~cm})$ through the phloem $(91,141)$. When a segment of a nontransgenic plant is grafted between silenced transgenic plants and nonsilenced transgenic plants, the silencing information is successfully transmitted through the nontransgenic tissue (91). Thus, aberrant transcripts made from transgenes are not required for propagation of the silencing signal via a relay mechanism as described for cell-to-cell transport through plasmodesmata. Furthermore, abolishing the expression of the tobacco ortholog of the RdRP RDR6 in plant stem sections does not prevent the transmission of the silencing signal through that section, showing that amplification is not required for transport of the silencing signal through the phloem (113). In contrast, reception of the phloem-transported silencing signal requires either abundant target molecules or amplification of the silencing signal $(36,93,113)$.

The molecular mechanism that controls phloem-dependent transport of silencing information is largely unknown. Although in one study phloem-dependent transport was found to be strictly correlated with the presence of 24-nt siRNAs (45), conflicting results suggest that phloem-dependent transport does not correlate with any RNA species (78). However, a phloem small $\underline{R N A}$-binding protein, PSRP1, has been isolated biochemically from pumpkin phloem sap and found to bind small RNAs with high affinity (153). Although PSRP1 preferentially binds to small RNAs, the precise nature and size of the RNA bound by PSRP1 during the transport of silencing information is unknown. Due to the low complexity of the PSRP1 sequence, clear homologs have not been identified in Arabidopsis or in 
tobacco. However, similar small RNA binding proteins were detected in the phloem saps of cucumber and lupine plants, suggesting that small RNAs involved in long-distance silencing may be transported through the phloem as parts of ribonucleoprotein complexes. Thus, the sequence-specific silencing signal that is transported through the phloem as well as the pathway responsible for its biogenesis and transport remain largely unclear.

\section{Lessons From Plant Viruses}

RNAi functions in plants as an antiviral defense mechanism (68). Infection with a virus triggers RNA silencing directed against the virus, while plants defective in RNAi show enhanced susceptibility to viral infection. Additionally, and most convincingly, viruses encode virulence factors that inhibit RNAi. Many viral suppressors of RNAi differentially affect cell-autonomous RNAi and the intercellular transport of silencing information providing insight into the regulation of these processes.

The generation and transport of silencing information is not dependent on efficient cellautonomous RNAi. In grafting experiments, HC-Pro protein of Potato virus $Y$ strongly inhibits cell autonomous RNAi, yet does not affect the long-distance transport of silencing information to grafted scions (78). In contrast, the p25 protein of Potato virus $X$ and the $2 \mathrm{~b}$ protein of a weak strain of Cucumber mosaic virus do not effectively inhibit cellautonomous RNAi, yet inhibit long-distance transport of silencing information $(43,140)$. Similarly, cell-to-cell and long-distance transport can be selectively inhibited by different viral proteins. The AC2 protein of African cassava mosaic virus eliminates cell-to-cell but not long-distance spread of silencing information, whereas the $\mathrm{P} 1$ protein of Rice yellow mottle virus eliminates long-distance but not cell-to-cell spread of silencing information (50). Finally, a GFP-tagged Turnip crinckle virus lacking the P38 suppressor protein was restricted to single cells from which the cell-to-cell transport of silencing information occurred but the long-distance transport of silencing information was inhibited (108).

Recent studies suggest that most plant viral suppressors can bind small RNAs and presumably suppress RNAi by sequestering them $(64,81)$. Similar studies that examine the biochemical functions of viral suppressor proteins may provide a mechanistic understanding of their effects on the intercellular transport of silencing information discussed above.

\section{EVOLUTIONARILY SELECTED ROLE OF SILENCING TRANSPORT MACHINERY?}

In plants, the silencing transport machinery appears to be part of a plant-wide antiviral response. In this paradigm, an infected plant cell sends a silencing signal ahead of the viral infection front to enable neighboring cells to mount a strong antiviral RNAi response and thus prevent the establishment of infection. Consistently, some plant viruses encode proteins that suppress the intercellular transport of silencing information during RNAi and such suppression is required for successful infection (68).

In animals, many components of the silencing transport machinery are highly conserved $(109,126,146)$, suggesting that this process was selected for over evolutionary time. 
Although no selected roles for the silencing transport machinery in animals are known, a few speculative possibilities are presented below.

\section{Sharing Silencing RNAs}

Antiviral response.-Cell-autonomous RNAi has been suggested to be an antiviral defense mechanism in worms $(74,112,145)$, in flies $(137,142)$, and in mosquitoes $(54,69)$. Unlike in invertebrates, it is difficult to evaluate whether RNAi is an antiviral mechanism in mammals (25) since dsRNA triggers a nonspecific response called the interferon response that causes degradation of all mRNA in somatic cells. Although several mammalian viruses express proteins that can inhibit RNAi in insect cells (69), some of these same proteins also inhibit the interferon response during viral infection of mammalian cells (53). This suggests that these viral proteins inhibit steps that are common to both the interferon and RNAi responses: e.g., recognition of dsRNA triggers. Furthermore, in mammalian cells, unlike in plants, viral infection does not inhibit RNAi (95). Thus, although the antiviral role (if any) of RNAi in mammals remains unclear, RNAi does appear to be an antiviral response in many invertebrates,

In contrast, it is unknown if the intercellular transport of silencing information during RNAi is part of an antiviral response in any animal, mainly because natural viruses that infect the well-studied animal model $C$. elegans are unknown and therefore studies akin to those described above in plants are not yet possible. The recent establishment of flock house virus (74), vesicular stomatitis virus $(112,145)$, and vaccinia virus (73) infection in C. elegans combined with the availability of well-characterized mutants defective in the intercellular transport of silencing such as sid-1 (146) could make it possible to evaluate if, as in plants, the transport of silencing is an antiviral response at least in some animals.

Noncell-autonomous control of gene regulation.-Endogenously made dsRNAs may also trigger the transport of gene regulatory information between cells. Most plants and animals express an abundant class of regulatory RNAs called micro RNAs (miRNAs). These RNAs are $~ 21 \mathrm{nt}$ long, are made from long dsRNAs, and regulate development and behavior by directing the translational repression or cleavage of cellular mRNAs (61). In addition, there are many sources of sense-antisense dsRNAs in the genome of plants (15), C. elegans (66), mice (59), and humans $(101,151)$. These dsRNAs may regulate diverse cellular processes: e.g., endogenous siRNAs derived from a natural sense-antisense pair in Arabidopsis controls salt tolerance (15). In all cases examined so far, noncell-autonomous effects have not been uncovered for the action of miRNAs or natural dsRNAs. However, an appealing hypothesis is that dsRNAs and miRNAs that are expressed in cells exposed to the environment are transported in response to specific environmental changes. A rigorous evaluation of this hypothesis requires experiments exploring the expression pattern of miRNAs under various environmental conditions.

\section{Sharing of Nonsilencing RNAs}

The transport of silencing information between cells during RNAi may use part of the same machinery as that used by some animal cells to transport proteins, mRNAs, and microRNAs between cells. Cultured cells can control neighboring cells by releasing vesicles called 
microvesicles (99), in the case of mouse embryonic stem cells, or called exosomes (135a), in the case of mouse and human mast cells, that contain select proteins and RNAs. When neighboring cells import these microvesicles or exosomes, the mRNA enters the cytoplasm through an unknown mechanism and is translated into functional protein. Similar vesicles called argosomes carry signaling molecules to neighboring cells during early development and pattern formation (39). If, as proposed here, the intercellular transport machinery for silencing information is also required for the transport of such essential molecules, why are developmental defects not observed in mutants defective in the intercellular transport of silencing information? All genetic screens performed in $C$. elegans thus far have been capable of isolating only viable and fertile mutants. Therefore, additional screens designed to isolate lethal or sterile mutants may uncover such essential genes that also mediate the intercellular transport of silencing information.

In recent years, large-scale sequencing of small RNAs has led to the discovery of many different kinds of abundant noncoding RNAs: endogenous secondary siRNAs (89) and 21-U siRNAs (106) in C. elegans, repeat-associated siRNAs (rasiRNAs) (10) and piwi-interacting RNAs (piRNAs) (16) in Drosophila, and piRNAs in mammals (9, 38, 42, 65, 143a). Some of these RNAs appear to arise from dsRNA precursors, while others are found associated with components of the RNAi machinery, but their biogenesis and roles remain unclear. The transport of these endogenous small RNAs or their precursors could potentially be a selected function of the silencing transport machinery.

\section{Experience-Dependent Inheritance}

A hen is only an egg's way of making another egg.

Samuel Butler

RNAi in C. elegans can be transmitted from somatic cells to the germline. Other examples of such epigenetic inheritance are also associated with regulatory double-stranded RNAs (156). For example, DNA methylation and/or heterochromatinization is associated with silenced copies of genes, and in mammals, the sex of the parent providing the chromosome affects which genes are silenced on that chromosome (imprinting) (148). Environmental or dietary changes in pregnant rats or mice, respectively, can also cause changes in DNA methylation and gene expression that are inherited stably through subsequent generations even in the absence of the initial dietary or environmental change $(7,24)$. Furthermore, in maize and in mice, the heterochromatinized state of certain dominant alleles can be transferred to homologous alleles apparently through the RdRP-dependent production of RNA from the dominant allele $(19,98)$. Thus, the silencing transport machinery may transport RNAs associated with heterochromatinization from somatic cells to the germline to confer an altered heterochromatin state and therefore altered gene expression in the next generation.

\section{PERSPECTIVE}

About a decade ago, Andrew Fire, Craig Mello, and coworkers made the seminal discovery that dsRNA is the trigger for a posttranscriptional gene silencing mechanism called RNAi (35). In addition to RNAi, dsRNA has been subsequently found to be involved in several diverse regulatory processes such as translational repression, transcriptional silencing, and 
DNA elimination. Similarly, the silencing information transported between cells during RNAi is perhaps just one of many forms of sequence-specific communication between cells that enable multicellular organisms to develop and function coordinately.

\section{ACKNOWLEDGMENTS}

We thank Daniel Chase, Edith Myers, Jessica Tanis, and members of the Hunter lab, particularly, Jacqueline Brooks, Daniel Schott, Jessica Smith, and Shai Shen-Orr for critical comments. We apologize for being unable to include the work of some colleagues due to space restrictions. This work was supported by awards from the American Heart Association to A.M.J., and from NSF (MCB 110452) and NIH (GM069891) to C.P.H.

\section{LITERATURE CITED}

1. Akiyama-Oda Y, Oda H. 2006 Axis specification in the spider embryo: dpp is required for radial-toaxial symmetry transformation and sog for ventral patterning. Development 133:2347-57 [PubMed: 16720876]

2. Alder MN, Dames S, Gaudet J, Mango SE. 2003 Gene silencing in Caenorhabditis elegans by transitive RNA interference. RNA 9:25-32 [PubMed: 12554873]

3. Aljamali MN, Bior AD, Sauer JR, Essenberg RC. 2003 RNA interference in ticks: a study using histamine binding protein dsRNA in the female tick Amblyomma americanum. Insect Mol. Biol 12:299-305 [PubMed: 12752664]

4. Alleman M, Sidorenko L, McGinnis K, Seshadri V, Dorweiler JE, et al. 2006 An RNA-dependent RNA polymerase is required for paramutation in maize. Nature 442:295-98 [PubMed: 16855589]

5. Ambros V, Lee RC, Lavanway A, Williams PT, Jewell D. 2003 MicroRNAs and other tiny endogenous RNAs in C. elegans. Curr. Biol 13:807-18 [PubMed: 12747828]

6. Amdam GV, Simoes ZL, Guidugli KR, Norberg K, Omholt SW. 2003 Disruption of vitellogenin gene function in adult honeybees by intra-abdominal injection of double-stranded RNA. BMC Biotechnol 3:1 [PubMed: 12546706]

7. Anway MD, Cupp AS, Uzumcu M, Skinner MK. 2005 Epigenetic transgenerational actions of endocrine disruptors and male fertility. Science 308:1466-69 [PubMed: 15933200]

8. Araujo RN, Santos A, Pinto FS, Gontijo NF, Lehane MJ, Pereira MH. 2006 RNA interference of the salivary gland nitrophorin 2 in the triatomine bug Rhodnius prolixus (Hemiptera: Reduviidae) by dsRNA ingestion or injection. Insect Biochem. Mol. Biol 36:683-93 [PubMed: 16935217]

9. Aravin A, Gaidatzis D, Pfeffer S, Lagos-Quintana M, Landgraf P, et al. 2006 A novel class of small RNAs bind to MILI protein in mouse testes. Nature 442:203-7 [PubMed: 16751777]

10. Aravin AA, Lagos-Quintana M, Yalcin A, Zavolan M, Marks D, et al. 2003 The small RNA profile during Drosophila melanogaster development. Dev. Cell 5:337-50 [PubMed: 12919683]

11. Bartholomay LC, Fuchs JF, Cheng LL, Beck ET, Vizioli J, et al. 2004 Reassessing the role of defensin in the innate immune response of the mosquito, Aedes aegypti. Insect Mol. Biol 13:12532 [PubMed: 15056359]

12. Bernstein E, Caudy AA, Hammond SM, Hannon GJ. 2001 Role for a bidentate ribonuclease in the initiation step of RNA interference. Nature 409:363-66 [PubMed: 11201747]

13. Billy E, Brondani V, Zhang H, Muller U, Filipowicz W. 2001 Specific interference with gene expression induced by long, double-stranded RNA in mouse embryonal teratocarcinoma cell lines. Proc. Natl. Acad. Sci. USA 98:14428-33 [PubMed: 11724966]

14. Blandin S, Moita LF, Kocher T, Wilm M, Kafatos FC, Levashina EA. 2002 Reverse genetics in the mosquito Anopheles gambiae: targeted disruption of the Defensin gene. EMBO Rep 3:852-56 [PubMed: 12189180]

15. Borsani O, Zhu J, Verslues PE, Sunkar R, Zhu JK. 2006 Endogenous siRNAs derived from a pair of natural cis antisense transcripts regulate salt tolerance in Arabidopsis. Cell 123:1279-91

16. Brennecke J, Aravin AA, Stark A, Dus M, Kellis M, et al. 2007 Discrete small RNA-generating loci as master regulators of transposon activity in Drosophila. Cell 128:1089-103 [PubMed: 17346786] 
17. Briese M, Esmaeili B, Johnson NM, Sattelle DB. 2006 pWormgatePro enables promoter-driven knockdown by hairpin RNA interference of muscle and neuronal gene products in Caenorhabditis elegans. Invert. Neurosci 6:5-12 [PubMed: 16432720]

18. Bucher G, Scholten J, Klingler M. 2002 Parental RNAi in Tribolium (Coleoptera). Curr. Biol 12:R85-86 [PubMed: 11839285]

19. Chandler VL. 2007 Paramutation: from maize to mice. Cell 128:641-45 [PubMed: 17320501]

20. Chang J, Taylor J. 2002 In vivo RNA-directed transcription, with template switching, by a mammalian RNA polymerase. EMBO J 21:157-64 [PubMed: 11782435]

21. Chera S, de Rosa R, Miljkovic-Licina M, Dobretz K, Ghila L, et al. 2006 Silencing of the hydra serine protease inhibitor Kazal1 gene mimics the human SPINK1 pancreatic phenotype. J. Cell Sci 119:846-57 [PubMed: 16478786]

22. Ciudad L, Piulachs MD, Belles X. 2006 Systemic RNAi of the cockroach vitellogenin receptor results in a phenotype similar to that of the Drosophila yolkless mutant. FEBS J 273:325-35 [PubMed: 16403020]

23. Crete P, Leuenberger S, Iglesias VA, Suarez V, Schob H, et al. 2001 Graft transmission of induced and spontaneous post-transcriptional silencing of chitinase genes. Plant J 28:493-501 [PubMed: 11849590]

24. Cropley JE, Suter CM, Beckman KB, Martin DIK. 2006 Germ-line epigenetic modification of the murine Avy allele by nutritional supplementation. Proc. Natl. Acad. Sci. USA 103:17308-12 [PubMed: 17101998]

25. Cullen BR. 2006 Is RNA interference involved in intrinsic antiviral immunity in mammals? Nat. Immunol 7:563-67 [PubMed: 16715068]

26. Dalmay T, Hamilton A, Rudd S, Angell S, Baulcombe DC. 2000 An RNA-dependent RNA polymerase gene in Arabidopsis is required for posttranscriptional gene silencing mediated by a transgene but not by a virus. Cell 101:543-53 [PubMed: 10850496]

27. Dong Y, Friedrich M. 2005 Nymphal RNAi: systemic RNAi mediated gene knockdown in juvenile grasshopper. BMC Biotechnol 5:25 [PubMed: 16202143]

28. Duchaine TF, Wohlschlegel JA, Kennedy S, Bei Y, Conte D Jr, et al. 2006 Functional proteomics reveals the biochemical niche of $C$. elegans DCR-1 in multiple small-RNA-mediated pathways. Cell 124:343-54 [PubMed: 16439208]

29. Dunoyer P, Himber C, Voinnet O. 2005 DICER-LIKE 4 is required for RNA interference and produces the 21-nucleotide small interfering RNA component of the plant cell-to-cell silencing signal. Nat. Genet 37:1356-60 [PubMed: 16273107]

30. Duxbury MS, Ashley SW, Whang EE. 2005 RNA interference: a mammalian SID-1 homologue enhances siRNA uptake and gene silencing efficacy in human cells. Biochem. Biophys. Res. Commun 331:459-63 [PubMed: 15850781]

31. Dzitoyeva S, Dimitrijevic N, Manev H. 2003 Gamma-aminobutyric acid B receptor 1 mediates behavior-impairing actions of alcohol in Drosophila: adult RNA interference and pharmacological evidence. Proc. Natl. Acad. Sci. USA 100:5485-90 [PubMed: 12692303]

32. Elbashir SM, Martinez J, Patkaniowska A, Lendeckel W, Tuschl T. 2001 Functional anatomy of siRNAs for mediating efficient RNAi in Drosophila melanogaster embryo lysate. EMBO J 20:6877-88 [PubMed: 11726523]

33. Eleftherianos I, Millichap PJ, ffrench-Constant RH, Reynolds SE. 2006 RNAi suppression of recognition protein mediated immune responses in the tobacco hornworm Manduca sexta causes increased susceptibility to the insect pathogen Photorhabdus. Dev. Comp. Immunol 30:1099-107 [PubMed: 16620974]

34. Feinberg EH, Hunter CP. 2003 Transport of dsRNA into cells by the transmembrane protein SID-1. Science 301:1545-47 [PubMed: 12970568]

35. Fire A, Xu S, Montgomery MK, Kostas SA, Driver SE, Mello CC. 1998 Potent and specific genetic interference by double-stranded RNA in Caenorhabditis elegans. Nature 391:806-11 [PubMed: 9486653]

36. Garcia-Perez RD, Houdt HV, Depicker A. 2004 Spreading of post-transcriptional gene silencing along the target gene promotes systemic silencing. Plant J 38:594-602 [PubMed: 15125766] 
37. Gazzani S, Lawrenson T, Woodward C, Headon D, Sablowski R. 2004 A link between mRNA turnover and RNA interference in Arabidopsis. Science 306:1046-48 [PubMed: 15528448]

38. Girard A, Sachidanandam R, Hannon GJ, Carmell MA. 2006 A germline-specific class of small RNAs binds mammalian Piwi proteins. Nature 442:199-202 [PubMed: 16751776]

39. Greco V, Hannus M, Eaton S. 2001 Argosomes: a potential vehicle for the spread of morphogens through epithelia. Cell 106:633-45 [PubMed: 11551510]

40. Grishok A, Tabara H, Mello CC. 2000 Genetic requirements for inheritance of RNAi in C. elegans. Science 287:2494-97 [PubMed: 10741970]

41. Grishok A 2005 RNAi mechanisms in Caenorhabditis elegans. FEBS Lett 579:5932-39 [PubMed: 16162338]

42. Grivna ST, Beyret E, Wang Z, Lin H. 2006 A novel class of small RNAs in mouse spermatogenic cells. Genes Dev 20:1709-14 [PubMed: 16766680]

43. Guo HS, Ding SW. 2002 A viral protein inhibits the long range signaling activity of the gene silencing signal. EMBO J 21:398-407 [PubMed: 11823432]

44. Guo HS, Fei JF, Xie Q, Chua NH. 2003 A chemical-regulated inducible RNAi system in plants. Plant J 34:383-92 [PubMed: 12713544]

45. Hamilton A, Voinnet O, Chappell L, Baulcombe D. 2002 Two classes of short interfering RNA in RNA silencing. EMBO J 21:4671-79 [PubMed: 12198169]

46. Hamilton AJ, Baulcombe DC. 1999 A species of small antisense RNA in posttranscriptional gene silencing in plants. Science 286:950-52 [PubMed: 10542148]

47. Hammond SM, Boettcher S, Caudy AA, Kobayashi R, Hannon GJ. 2001 Argonaute2, a link between genetic and biochemical analyses of RNAi. Science 293:1146-50 [PubMed: 11498593]

48. He ZB, Cao YQ, Yin YP, Wang ZK, Chen B, et al. 2006 Role of hunchback in segment patterning of Locusta migratoria manilensis revealed by parental RNAi. Dev. Growth Differ 48:439-45 [PubMed: 16961591]

49. Hewezi T, Alibert G, Kallerhoff J. 2005 Local infiltration of high- and low-molecular-weight RNA from silenced sunflower (Helianthus annuus L.) plants triggers post-transcriptional gene silencing in nonsilenced plants. Plant Biotechnol. J 3:81-89 [PubMed: 17168901]

50. Himber C, Dunoyer P, Moissiard G, Ritzenthaler C, Voinnet O. 2003 Transitivity-dependent and independent cell-to-cell movement of RNA silencing. EMBO J 22:4523-33 [PubMed: 12941703]

51. Deleted in Proof

52. Kalinna BH, Brindley PJ. 2007 Manipulating the manipulators: advances in parasitic helminth transgenesis and RNAi. Trends Parasitol 23:197-204 [PubMed: 17383233]

53. Katze MG, He Y, Gale M Jr. 2002 Viruses and interferon: a fight for supremacy. Nat. Rev. Immunol 2:675-87 [PubMed: 12209136]

54. Keene KM, Foy BD, Sanchez-Vargas I, Beaty BJ, Blair CD, Olson KE. 2004 RNA interference acts as a natural antiviral response to O'nyong-nyong virus (Alphavirus; Togaviridae) infection of Anopheles gambiae. Proc. Natl. Acad. Sci. USA 101:17240-45 [PubMed: 15583140]

55. Kennedy S, Wang D, Ruvkun G. 2004 A conserved siRNA-degrading RNase negatively regulates RNA interference in C. elegans. Nature 427:645-49 [PubMed: 14961122]

56. Kennerdell JR, Carthew RW. 1998 Use of dsRNA-mediated genetic interference to demonstrate that frizzled and frizzled 2 act in the wingless pathway. Cell 95:1017-26 [PubMed: 9875855]

57. Kim JK, Gabel HW, Kamath RS, Tewari M, Pasquinelli A, et al. 2005 Functional genomic analysis of RNA interference in C. elegans. Science 308:1164-67 [PubMed: 15790806]

58. Kimber MJ, McKinney S, McMaster S, Day TA, Fleming CC, Maule AG. 2007 flp gene disruption in a parasitic nematode reveals motor dysfunction and unusual neuronal sensitivity to RNA interference. FASEB J 21:1233-43 [PubMed: 17200420]

59. Kiyosawa H, Mise N, Iwase S, Hayashizaki Y, Abe K. 2005 Disclosing hidden transcripts: mouse natural sense-antisense transcripts tend to be poly(A) negative and nuclear localized. Genome Res 15:463-74 [PubMed: 15781571]

60. Klahre U, Crete P, Leuenberger SA, Iglesias VA, Meins F Jr. 2002 High molecular weight RNAs and small interfering RNAs induce systemic posttranscriptional gene silencing in plants. Proc. Natl. Acad. Sci. USA 99:11981-86 [PubMed: 12181491] 
61. Kloosterman WP, Plasterk RH. 2006 The diverse functions of microRNAs in animal development and disease. Dev. Cell 11:441-50 [PubMed: 17011485]

62. Knight SW, Bass BL. 2001 A role for the RNase III enzyme DCR-1 in RNA interference and germ line development in Caenorhabditis elegans. Science 293:2269-71 [PubMed: 11486053]

63. Krutzfeldt J, Rajewsky N, Braich R, Rajeev KG, Tuschl T, et al. 2005 Silencing of microRNAs in vivo with 'antagomirs'. Nature 438:685-89 [PubMed: 16258535]

64. Lakatos L, Csorba T, Pantaleo V, Chapman EJ, Carrington JC, et al. 2006 Small RNA binding is a common strategy to suppress RNA silencing by several viral suppressors. EMBO J 25:2768-80 [PubMed: 16724105]

65. Lau NC, Seto AG, Kim J, Kuramochi-Miyagawa S, Nakano T, et al. 2006 Characterization of the piRNA complex from rat testes. Science 313:363-67 [PubMed: 16778019]

66. Lee RC, Hammell CM, Ambros V. 2006 Interacting endogenous and exogenous RNAi pathways in Caenorhabditis elegans. RNA 12:589-97 [PubMed: 16489184]

67. Legendre-Guillemin V, Wasiak S, Hussain NK, Angers A, McPherson PS. 2004 ENTH/ANTH proteins and clathrin-mediated membrane budding. J. Cell Sci 117:9-18 [PubMed: 14657269]

68. Li F, Ding SW. 2006 Virus counterdefense: diverse strategies for evading the RNA-silencing immunity. Annu. Rev. Microbiol 60:503-31 [PubMed: 16768647]

69. Li WX, Li H, Lu R, Li F, Dus M, et al. 2004 Interferon antagonist proteins of influenza and vaccinia viruses are suppressors of RNA silencing. Proc. Natl. Acad. Sci. USA 101:1350-55 [PubMed: 14745017]

70. Limpens E, Ramos J, Franken C, Raz V, Compaan B, et al. 2004 RNA interference in Agrobacterium rhizogenes-transformed roots of Arabidopsis and Medicago truncatula. J. Exp. Bot 55:983-92 [PubMed: 15073217]

71. Liu J, Carmell MA, Rivas FV, Marsden CG, Thomson JM, et al. 2004 Argonaute2 is the catalytic engine of mammalian RNAi. Science 305:1437-41 [PubMed: 15284456]

72. Liu PZ, Kaufman TC. 2004 hunchback is required for suppression of abdominal identity, and for proper germband growth and segmentation in the intermediate germband insect Oncopeltus fasciatus. Development 131:1515-27 [PubMed: 14998925]

73. Liu WH, Lin YL, Wang JP, Liou W, Hou RF, et al. 2006 Restriction of vaccinia virus replication by a ced-3 and ced-4-dependent pathway in Caenorhabditis elegans. Proc. Natl. Acad. Sci. USA 103:4174-79 [PubMed: 16537504]

74. Lu R, Maduro M, Li F, Li HW, Broitman-Maduro G, et al. 2005 Animal virus replication and RNAi-mediated antiviral silencing in Caenorhabditis elegans. Nature 436:1040-43 [PubMed: 16107851]

75. Lynch JA, Brent AE, Leaf DS, Pultz MA, Desplan C. 2006 Localized maternal orthodenticle patterns anterior and posterior in the long germ wasp Nasonia. Nature 439:728-32 [PubMed: 16467838]

76. Maine EM, Hauth J, Ratliff T, Vought VE, She X. 2005 EGO-1, a putative RNA-dependent RNA polymerase, is required for heterochromatin assembly on unpaired dna during $C$. elegans meiosis. Curr. Biol 15:1972-78 [PubMed: 16271877]

77. Malhotra P, Dasaradhi PV, Kumar A, Mohmmed A, Agrawal N, et al. 2002 Double-stranded RNAmediated gene silencing of cysteine proteases (falcipain-1 and -2) of Plasmodium falciparum. Mol. Microbiol 45:1245-54 [PubMed: 12207693]

78. Mallory AC, Mlotshwa S, Bowman LH, Vance VB. 2003 The capacity of transgenic tobacco to send a systemic RNA silencing signal depends on the nature of the inducing transgene locus. Plant J 35:82-92 [PubMed: 12834404]

79. Marie B, Bacon JP, Blagburn JM. 2000 Double-stranded RNA interference shows that Engrailed controls the synaptic specificity of identified sensory neurons. Curr. Biol 10:289-92 [PubMed: 10712910]

80. Mathey-Prevot B, Perrimon N. 2006 Drosophila genome-wide RNAi screens: Are they delivering the promise? Cold Spring Harbor Symp. Quant. Biol 71:141-48 [PubMed: 17381290]

81. Merai Z, Kerenyi Z, Kertesz S, Magna M, Lakatos L, Silhavy D. 2006 Double-stranded RNA binding may be a general plant RNA viral strategy to suppress RNA silencing. J. Virol 80:5747-56 [PubMed: 16731914] 
82. Mito T, Sarashina I, Zhang H, Iwahashi A, Okamoto H, et al. 2005 Non-canonical functions of hunchback in segment patterning of the intermediate germ cricket Gryllus bimaculatus. Development 132:2069-79 [PubMed: 15788457]

83. Mourrain P, Beclin C, Elmayan T, Feuerbach F, Godon C, et al. 2000 Arabidopsis SGS2 and SGS3 genes are required for posttranscriptional gene silencing and natural virus resistance. Cell 101:533-42 [PubMed: 10850495]

84. Newmark PA, Reddien PW, Cebria F, Sanchez Alvarado A. 2003 Ingestion of bacterially expressed double-stranded RNA inhibits gene expression in planarians. Proc. Natl. Acad. Sci. USA 100(Suppl. 1):11861-65 [PubMed: 12917490]

85. Ngo H, Tschudi C, Gull K, Ullu E. 1998 Double-stranded RNA induces mRNA degradation in Trypanosoma brucei. Proc. Natl. Acad. Sci. USA 95:14687-92 [PubMed: 9843950]

86. Nishikawa T, Natori S. 2001 Targeted disruption of a pupal hemocyte protein of Sarcophaga by RNA interference. Eur. J. Biochem 268:5295-99 [PubMed: 11606191]

87. Overhoff M, Sczakiel G. 2005 Phosphorothioate-stimulated uptake of short interfering RNA by human cells. EMBO Rep 6:1176-81 [PubMed: 16170302]

88. Paddison PJ, Caudy AA, Hannon GJ. 2002 Stable suppression of gene expression by RNAi in mammalian cells. Proc. Natl. Acad. Sci. USA 99:1443-48 [PubMed: 11818553]

89. Pak J, Fire A. 2007 Distinct populations of primary and secondary effectors during RNAi in $C$. elegans. Science 315:241-44 [PubMed: 17124291]

90. Palauqui JC, Elmayan T, De Borne FD, Crete P, Charles C, Vaucheret H. 1996 Frequencies, timing, and spatial patterns of co-suppression of nitrate reductase and nitrite reductase in transgenic tobacco plants. Plant Physiol 112:1447-56 [PubMed: 12226457]

91. Palauqui JC, Elmayan T, Pollien JM, Vaucheret H. 1997 Systemic acquired silencing: transgenespecific post-transcriptional silencing is transmitted by grafting from silenced stocks to nonsilenced scions. EMBO J 16:4738-45 [PubMed: 9303318]

92. Palauqui JC, Vaucheret H. 1995 Field trial analysis of nitrate reductase cosuppression: a comparative study of 38 combinations of transgene loci. Plant Mol. Biol 29:149-59 [PubMed: 7579160]

93. Palauqui JC, Vaucheret H. 1998 Transgenes are dispensable for the RNA degradation step of cosuppression. Proc. Natl. Acad. Sci. USA 95:9675-80 [PubMed: 9689140]

94. Parrish S, Fire A. 2001 Distinct roles for RDE-1 and RDE-4 during RNA interference in Caenorhabditis elegans. RNA 7:1397-402 [PubMed: 11680844]

95. Pfeffer S, Sewer A, Lagos-Quintana M, Sheridan R, Sander C, et al. 2005 Identification of microRNAs of the herpesvirus family. Nat. Methods 2:269-76 [PubMed: 15782219]

96. Pineda D, Gonzalez J, Callaerts P, Ikeo K, Gehring WJ, Salo E. 2000 Searching for the prototypic eye genetic network: Sine oculis is essential for eye regeneration in planarians. Proc. Natl. Acad. Sci. USA 97:4525-29 [PubMed: 10781056]

97. Rajagopal R, Sivakumar S, Agrawal N, Malhotra P, Bhatnagar RK. 2002 Silencing of midgut aminopeptidase N of Spodoptera litura by double-stranded RNA establishes its role as Bacillus thuringiensis toxin receptor. J. Biol. Chem 277:46849-51 [PubMed: 12377776]

98. Rassoulzadegan M, Grandjean V, Gounon P, Vincent S, Gillot I, Cuzin F. 2006 RNA-mediated nonmendelian inheritance of an epigenetic change in the mouse. Nature 441:469-74 [PubMed: 16724059]

99. Ratajczak J, Miekus K, Kucia M, Zhang J, Reca R, et al. 2006 Embryonic stem cell-derived microvesicles reprogram hematopoietic progenitors: evidence for horizontal transfer of mRNA and protein delivery. Leukemia 20:847-56 [PubMed: 16453000]

100. Reynolds A, Anderson EM, Vermeulen A, Fedorov Y, Robinson K, et al. 2006 Induction of the interferon response by siRNA is cell type- and duplex length-dependent. RNA 12:988-93 [PubMed: 16611941]

101. RIKEN Genome Explor. Res. Group, Genome Sci. Group (Genome Network Project Core Group), FANTOM Consort. 2005 Antisense transcription in the mammalian transcriptome. Science 309:1564-66 [PubMed: 16141073]

102. Robalino J, Bartlett T, Shepard E, Prior S, Jaramillo G, et al. 2005 Double-stranded RNA induces sequence-specific antiviral silencing in addition to nonspecific immunity in a marine shrimp: 
convergence of RNA interference and innate immunity in the invertebrate antiviral response? J. Virol 79:13561-71 [PubMed: 16227276]

103. Robbins MA, Li M, Leung I, Li H, Boyer DV, et al. 2006 Stable expression of shRNAs in human $\mathrm{CD} 4^{+}$progenitor cells can avoid induction of interferon responses to siRNAs in vitro. Nat. Biotechnol 24:566-71 [PubMed: 16648841]

104. Roignant JY, Carre C, Mugat B, Szymczak D, Lepesant JA, Antoniewski C. 2003 Absence of transitive and systemic pathways allows cell-specific and isoform-specific RNAi in Drosophila. RNA 9:299-308 [PubMed: 12592004]

105. Romano N, Macino G. 1992 Quelling: transient inactivation of gene expression in Neurospora crassa by transformation with homologous sequences. Mol. Microbiol 6:3343-53 [PubMed: 1484489]

106. Ruby JG, Jan C, Player C, Axtell MJ, Lee W, et al. 2006 Large-scale sequencing reveals $21 \mathrm{U}$ RNAs and additional microRNAs and endogenous siRNAs in C. elegans. Cell 127:1193-207 [PubMed: 17174894]

107. Rutherford G, Tanurdzic M, Hasebe M, Banks JA. 2004 A systemic gene silencing method suitable for high throughput, reverse genetic analyses of gene function in fern gametophytes. BMC Plant Biol 4:6 [PubMed: 15090074]

108. Ryabov EV, van Wezel R, Walsh J, Hong Y. 2004 Cell-to-cell, but not long-distance, spread of RNA silencing that is induced in individual epidermal cells. J. Virol 78:3149-54 [PubMed: 14990735]

109. Saleh MC, van Rij RP, Hekele A, Gillis A, Foley E, et al. 2006 The endocytic pathway mediates cell entry of dsRNA to induce RNAi silencing. Nat. Cell Biol 8:793-802 [PubMed: 16862146]

110. Samuel CE. 2001 Antiviral actions of interferons. Clin. Microbiol. Rev 14:778-809 [PubMed: 11585785]

111. Schoppmeier M, Damen WGM. 2001 Double-stranded RNA interference (RNAi) in the spider Cupiennius salei: the role of Distal-less is evolutionary conserved. Dev. Genes Evol 211:76-82 [PubMed: 11455417]

112. Schott DH, Cureton DK, Whelan SP, Hunter CP. 2005 An antiviral role for the RNA interference machinery in Caenorhabditis elegans. Proc. Natl. Acad. Sci. USA 102:18420-24 [PubMed: 16339901]

113. Schwach F, Vaistij FE, Jones L, Baulcombe DC. 2005 An RNA-dependent RNA polymerase prevents meristem invasion by potato virus $\mathrm{X}$ and is required for the activity but not the production of a systemic silencing signal. Plant Physiol 138:1842-52 [PubMed: 16040651]

114. Shiu PK, Raju NB, Zickler D, Metzenberg RL. 2001 Meiotic silencing by unpaired DNA. Cell 107:905-16 [PubMed: 11779466]

115. Sijen T, Fleenor J, Simmer F, Thijssen KL, Parrish S, et al. 2001 On the role of RNA amplification in dsRNA-triggered gene silencing. Cell 107:465-76 [PubMed: 11719187]

116. Sijen T, Steiner FA, Thijssen KL, Plasterk RH. 2007 Secondary siRNAs result from unprimed RNA synthesis and form a distinct class. Science 315:244-47 [PubMed: 17158288]

117. Soares CA, Lima CM, Dolan MC, Piesman J, Beard CB, Zaidner NS. 2005 Capillary feeding of specific dsRNA induces silencing of the isac gene in nymphal Ixodes scapularis ticks. Insect Mol. Biol 14:443-52 [PubMed: 16033437]

118. Soutschek J, Akinc A, Bramlage B, Charisse K, Constien R, et al. 2004 Therapeutic silencing of an endogenous gene by systemic administration of modified siRNAs. Nature 432:173-78 [PubMed: 15538359]

119. Strat A, Gao L, Utsuki T, Cheng B, Nuthalapaty S, et al. 2006 Specific and nontoxic silencing in mammalian cells with expressed long dsRNAs. Nucleic Acids Res 34:3803-10 [PubMed: 16916791]

120. Sukumaran B, Narasimhan S, Anderson JF, DePonte K, Marcantonio N, et al. 2006 An Ixodes scapularis protein required for survival of Anaplasma phagocytophilum in tick salivary glands. J. Exp. Med 203:1507-17 [PubMed: 16717118]

121. Tabara H, Grishok A, Mello CC. 1998 RNAi in C. elegans: soaking in the genome sequence. Science 282:430-31 [PubMed: 9841401] 
122. Tabara H, Sarkissian M, Kelly WG, Fleenor J, Grishok A, et al. 1999 The rde-1 gene, RNA interference, and transposon silencing in C. elegans. Cell 99:123-32 [PubMed: 10535731]

123. Tabunoki H, Higurashi S, Ninagi O, Fujii H, Banno Y, et al. 2004 A carotenoid-binding protein (CBP) plays a crucial role in cocoon pigmentation of silkworm (Bombyx mori) larvae. FEBS Lett 567:175-78 [PubMed: 15178318]

124. Tavernarakis N, Wang SL, Dorovkov M, Ryazanov A, Driscoll M. 2000 Heritable and inducible genetic interference by double-stranded RNA encoded by transgenes. Nat. Genet 24:180-83 [PubMed: 10655066]

125. Tijsterman M, Ketting RF, Okihara KL, Sijen T, Plasterk RH. 2002 RNA helicase MUT-14dependent gene silencing triggered in $C$. elegans by short antisense RNAs. Science 295:694-97 [PubMed: 11809977]

126. Tijsterman M, May RC, Simmer F, Okihara KL, Plasterk RH. 2004 Genes required for systemic RNA interference in Caenorhabditis elegans. Curr. Biol 14:111-16 [PubMed: 14738731]

127. Timmons L, Fire A. 1998 Specific interference by ingested dsRNA. Nature 395:854 [PubMed: 9804418]

128. Timmons L, Tabara H, Mello CC, Fire AZ. 2003 Inducible systemic RNA silencing in Caenorhabditis elegans. Mol. Biol. Cell 14:2972-83 [PubMed: 12857879]

129. Tomoyasu Y, Denell RE. 2004 Larval RNAi in Tribolium (Coleoptera) for analyzing adult development. Dev. Genes Evol 214:575-78 [PubMed: 15365833]

130. Tournier B, Tabler M, Kalantidis K. 2006 Phloem flow strongly influences the systemic spread of silencing in GFP Nicotiana benthamiana plants. Plant J 47:383-94 [PubMed: 16771840]

131. Tran N, Raponi M, Dawes IW, Arndt GM. 2004 Control of specific gene expression in mammalian cells by coexpression of long complementary RNAs. FEBS Lett 573:127-34 [PubMed: 15327987]

132. Turner CT, Davy MW, MacDiarmid RM, Plummer KM, Birch NP, Newcomb RD. 2006 RNA interference in the light brown apple moth, Epiphyas postvittana (Walker) induced by doublestranded RNA feeding. Insect Mol. Biol 15:383-91 [PubMed: 16756557]

133. Turner JM, Mahadevaiah SK, Fernandez-Capetillo O, Nussenzweig A, Xu X, et al. 2005 Silencing of unsynapsed meiotic chromosomes in the mouse. Nat. Genet 37:41-47 [PubMed: 15580272]

134. Ulvila J, Parikka M, Kleino A, Sormunen R, Ezekowitz RA, et al. 2006 Double-stranded RNA is internalized by scavenger receptor-mediated endocytosis in Drosophila S2 cells. J. Biol. Chem 281:14370-75 [PubMed: 16531407]

135. Vagin VV, Sigova A, Li C, Seitz H, Gvozdev V, Zamore PD. 2006 A distinct small RNA pathway silences selfish genetic elements in the germline. Science 313:320-24 [PubMed: 16809489]

135a. Valadi H, Ekstrom K, Bossios A, Sjostrand M, Lee JJ, et al. 2007 Exosome-mediated transfer of mRNAs and microRNAs is a novel mechanism of genetic exchange between cells. Nat. Cell Biol 9:654-59 [PubMed: 17486113]

136. van Blokland N, van der Geest N, Mol JNM, Kooter JM. 1994 Transgenemediated suppression of chalcone synthase expression in Petunia hybrida results from an increase in RNA turnover. Plant J 6:861-77

137. van Rij RP, Saleh MC, Berry B, Foo C, Houk A, et al. 2006 The RNA silencing endonuclease Argonaute 2 mediates specific antiviral immunity in Drosophila melanogaster. Genes Dev 20:2985-95 [PubMed: 17079687]

138. Vastenhouw NL, Brunschwig K, Okihara KL, Muller F, Tijsterman M, Plasterk RH. 2006 Gene expression: long-term gene silencing by RNAi. Nature 442:882 [PubMed: 16929289]

139. Voinnet O, Baulcombe DC. 1997 Systemic signaling in gene silencing. Nature 389:553 [PubMed: 9335491]

140. Voinnet O, Lederer C, Baulcombe DC. 2000 A viral movement protein prevents spread of the gene silencing signal in Nicotiana benthamiana. Cell 103:157-67 [PubMed: 11051555]

141. Voinnet O, Vain P, Angell S, Baulcombe DC. 1998 Systemic spread of sequence-specific transgene RNA degradation in plants is initiated by localized introduction of ectopic promoterless DNA. Cell 95:177-87 [PubMed: 9790525] 
142. Wang XH, Aliyari R, Li WX, Li HW, Kim K, et al. 2006 RNA interference directs innate immunity against viruses in adult Drosophila. Science 312:452-54 [PubMed: 16556799]

143. Wasiak S, Legendre-Guillemin V, Puertollano R, Blondeau F, Girard M, et al. 2002 Enthoprotin: a novel clathrin-associated protein identified through subcellular proteomics. J. Cell Biol 158:85562 [PubMed: 12213833]

143a. Watanabe T, Takeda A, Tsukiyama T, Mise K, Okuno T, et al. 2006 Identification and characterization of two novel classes of small RNAs in the mouse germline: retrotransposonderived siRNAs in oocytes and germline small RNAs in testes. Genes Dev 20:1732-43 [PubMed: 16766679]

144. Waterhouse PM, Graham MW, Wang MB. 1998 Virus resistance and gene silencing in plants can be induced by simultaneous expression of sense and antisense RNA. Proc. Natl. Acad. Sci. USA 95:13959-64 [PubMed: 9811908]

145. Wilkins C, Dishongh R, Moore SC, Whitt MA, Chow M, Machaca K. 2005 RNA interference is an antiviral defense mechanism in Caenorhabditis elegans. Nature 436:1044-47 [PubMed: 16107852]

146. Winston WM, Molodowitch C, Hunter CP. 2002 Systemic RNAi in C. elegans requires the putative transmembrane protein SID-1. Science 295:2456-59 [PubMed: 11834782]

147. Winston WM, Sutherlin M, Wright AJ, Feinberg EH, Hunter CP. 2007 Caenorhabditis elegans SID-2 is required for environmental RNA interference. Proc. Natl. Acad. Sci. USA 104:1056570 [PubMed: 17563372]

148. Yang PK, Kuroda MI. 2007 Noncoding RNAs and intranuclear positioning in monoallelic gene expression. Cell 128:777-86 [PubMed: 17320513]

149. Yang S, Tutton S, Pierce E, Yoon K. 2001 Specific double-stranded RNA interference in undifferentiated mouse embryonic stem cells. Mol. Cell Biol 21:7807-16 [PubMed: 11604515]

150. Yao MC, Chao JL. 2005 RNA-guided DNA deletion in Tetrahymena: an RNAi-based mechanism for programmed genome rearrangements. Annu. Rev. Genet 39:537-59 [PubMed: 16285871]

151. Yelin R, Dahary D, Sorek R, Levanon EY, Goldstein O, et al. 2003 Widespread occurrence of antisense transcription in the human genome. Nat. Biotechnol 21:379-86 [PubMed: 12640466]

152. Yigit E, Batista PJ, Bei Y, Pang KM, Chen CC, et al. 2006 Analysis of the $C$. elegans Argonaute family reveals that distinct Argonautes act sequentially during RNAi. Cell 127:747-57 [PubMed: 17110334]

153. Yoo BC, Kragler F, Varkonyi-Gasic E, Haywood V, Archer-Evans S, et al. 2000 A systemic small RNA signaling system in plants. Plant Cell 16:1979-2000

154. Zambryski P 2004 Cell-to-cell transport of proteins and fluorescent tracers via plasmodesmata during plant development. J. Cell. Biol 164:165-68 [PubMed: 14734529]

155. Zamore PD, Tuschl T, Sharp PA, Bartel DP. 2000 RNAi: double-stranded RNA directs the ATPdependent cleavage of mRNA at 21 to 23 nucleotide intervals. Cell 101:25-33 [PubMed: 10778853]

156. Zaratiegui M, Irvine DV, Martienssen RA. 2007 Noncoding RNAs and gene silencing. Cell 128:763-76 [PubMed: 17320512]

157. Zhao G, Chang KY, Varley K, Stormo GD. 2007 Evidence for active maintenance of inverted repeat structures identified by a comparative genomic approach. PLoS ONE 2:e26

158. Zhou X, Oi FM, Scharf ME. 2006 Social exploitation of hexamerin: RNAi reveals a major casteregulatory factor in termites. Proc. Natl. Acad. Sci. USA 103:4499-504 [PubMed: 16537425] 
dsRNA: double-stranded RNA 
siRNA: short-interfering RNA 
Noncell autonomous effects: effects in naïve cells resulting from processes such as RNAi in other cells 
Hairpin RNA: a form of dsRNA typically generated when the mRNA product of an inverted-repeat sequence folds back on itself 


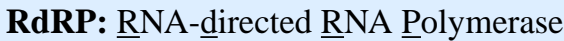


Inverted-repeat sequence: a pair of linked DNA sequences that are the reversed complement of each other 
Heterochromatinization: the condensation of transcriptionally active euchromatin into silenced heterochromatin 
Grafting: the process of joining a stem or a bud of one plant (scion) to the stem of another (rootstock) 
Epigenetic inheritance: transmission of information from one generation to the next without encoding it in the DNA sequence 


\section{RNAi IN C. ELEGANS}

A current model of cell-autonomous RNAi that incorporates key recent discoveries is presented below $(28,89,106,116,152)$. When trigger dsRNA enters a cell, it is processed into 21-nt primary siRNAs by the RNase III-like enzyme DCR-1 (62). Primary siRNAs complementary to target mRNA are bound by the RNase H-like primary Argonaute RDE-1, which is part of the RNA-induced silencing complex (RISC). Subsequent cleavage of target mRNA by the primary siRNA-programmed RISC recruits a cellular RNA-directed RNA Polymerase (RdRP) such as RRF-1 to produce $\sim 21$-nt secondary siRNA by target mRNA-directed unprimed synthesis. These secondary siRNAs associate with secondary Argonautes such as SAGO-1, which likely require additional proteins for activity. Subsequent steps that eventually lead to silencing are still unclear. An analogous parallel pathway processes dsRNAs endogenously made within the cell for silencing. For example, endogenous primary siRNAs bind the primary Argonaute ERGO-1 and endogenous secondary siRNAs are likely generated by the RdRP RRF-3. However, secondary siRNAs generated from both endogenous and exogenous pathways compete for association with the same secondary Argonautes. Thus, RNAi triggered by exogenously introduced dsRNA competes with RNAi triggered by endogenous dsRNA. Additional RNAi components $(41,57)$ have been omitted from the above model for simplicity. 


\section{SUMMARY POINTS}

1. In eukaryotic cells, double-stranded RNA triggers the silencing of genes with matching sequences through a process called RNA interference. In plants and in some animals, this sequence-specific silencing information is transported between cells. As a result, the same genes are silenced even in distant cells that did not initially encounter the double-stranded RNA.

2. Studies in the animal model $C$. elegans suggest that a form of long doublestranded RNA likely carries the sequence-specific information between cells during RNAi. Specific endocytosis machinery and a nucleic acid channel, SID-1, control the entry of the silencing signal into cells. The precise identity of the silencing signal and how it is exported out of cells are unknown.

3. Plants use two different mechanisms, both distinct from that of C. elegans, to transport silencing information. First, the silencing information (likely in the form of 21-nt siRNA) is transported to adjacent cells through dynamic intercellular bridges called plasmodesmata. This form of transport has a range of $\sim 10-15$ cells, but can extend further if the transported signal is amplified. In a second mechanism, an unknown silencing signal can be transported over long $(\sim 20 \mathrm{~cm})$ distances through the phloem vascular tissue.

4. RNAi acts as an antiviral mechanism in plants and at least in some animals. Several plant viruses encode proteins that suppress the transport of silencing information between cells, suggesting that intercellular transport of silencing evolved as a defense mechanism against viruses. A similar role for intercellular transport of silencing has not been shown in animals.

5. In addition to an antiviral role, several speculative roles can be envisioned for the transport of sequence-specific information between animal cells: e.g., noncell-autonomous gene regulation, sharing regulatory RNAs among cells during times of stress, conveying somatic experience to the germline, etc. Further experiments are required to determine which of these, if any, are the evolutionarily selected roles of the silencing transport machinery. 


\section{FUTURE ISSUES}

1. What is the biochemical nature of the silencing signal transported between cells? Is it the RNAi trigger dsRNA or some other modified/derived signal? How is this signal produced and regulated?

2. Why does the efficiency of transport of silencing information between cells vary with different trigger dsRNAs? Is dsRNA from the environment transported differently from dsRNA made within the cells of an organism? How is the transport of silencing between cells regulated?

3. What is the evolutionarily selected function of the intercellular transport machinery? Is it to transport silencing information or was this machinery selected for another role?

4. Do mammals transport RNAs between cells? 

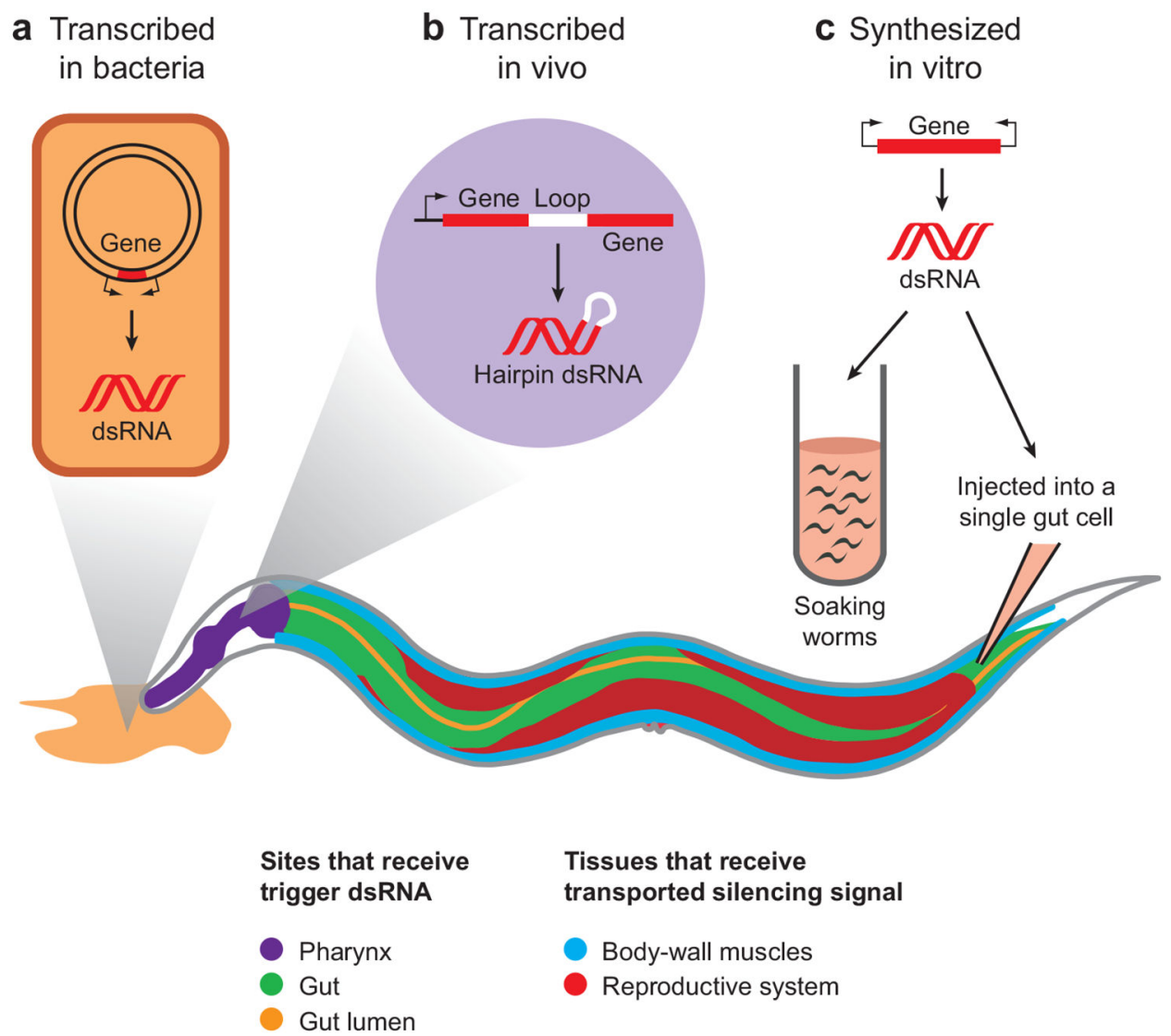

Figure 1.

The transport of silencing information between cells can be triggered in many ways in $C$. elegans. (a) When worms are either fed bacteria that express dsRNA or soaked in a dsRNA solution, the dsRNA is imported from the gut lumen into gut cells, and is disseminated to distant sites such as body-wall muscles and the reproductive system, presumably through the pseudocoelomic fluid (not shown), which bathes all tissues. Transcription start sites (small black arrows) and DNA (bacterial plasmid, PCR product, or inverted-repeat transgene) with target gene are shown. (b) Hairpin dsRNA made in vivo in the pharynx and (c) dsRNA injected into single gut cells likely also cause silencing to spread to other tissues via the pseudocoelom. 

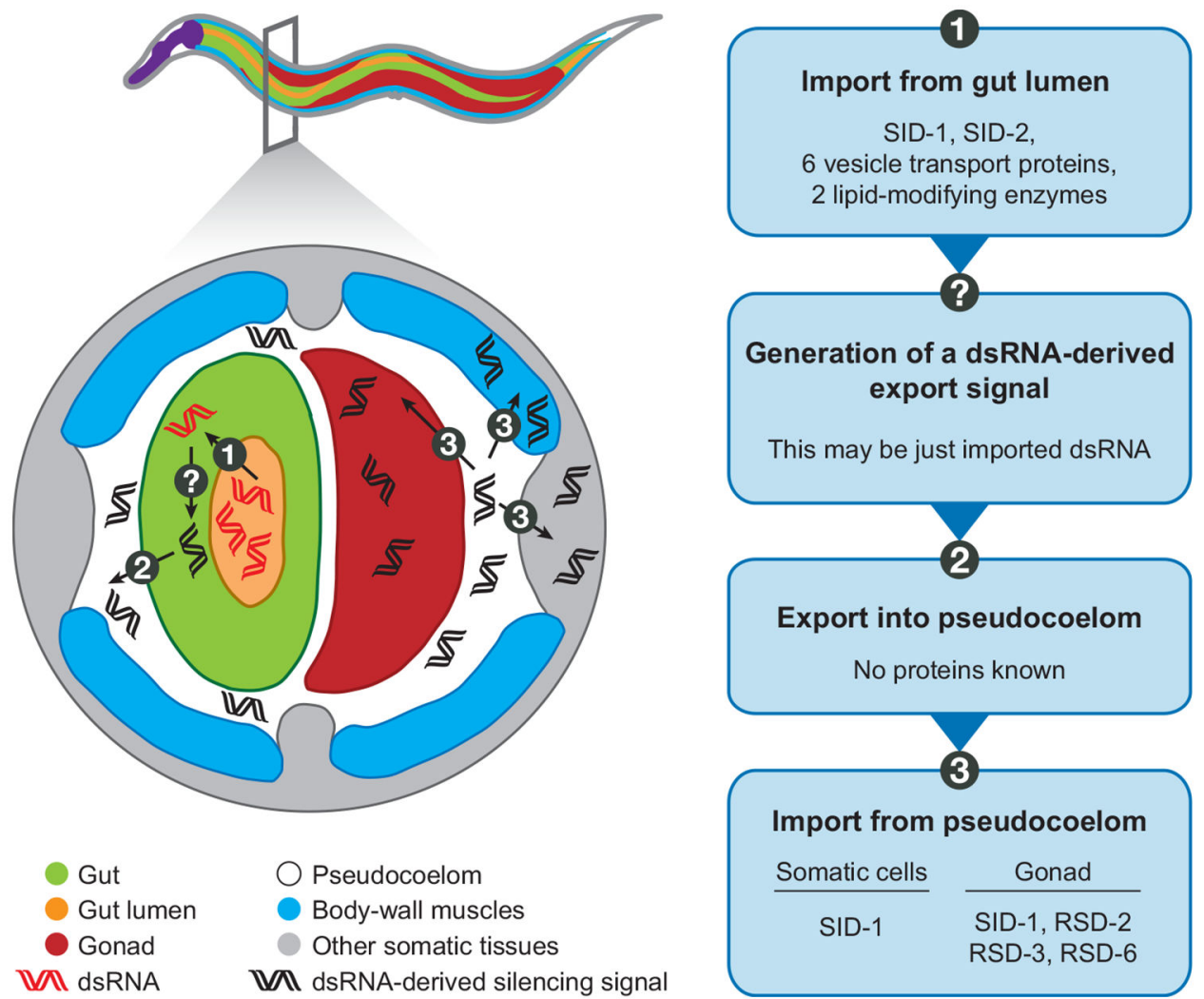

Figure 2.

Part of the molecular machinery that controls the uptake of dsRNA and mediates intercellular transport of silencing in $C$. elegans is known. A cross-section through the worm shows the transport of dsRNA and a dsRNA-derived silencing signal during RNAi. dsRNA is first imported from the gut lumen into gut cells. Imported dsRNA is either converted into a derived silencing signal and then exported or is directly exported out of gut cells into the pseudocoelom. The silencing signal is finally imported into the gonad and into body-wall muscles and other somatic tissues. The flowchart on the right shows the steps and proteins required during the intercellular transport of silencing. SID-1/RSD-8 is a dsRNA channel; SID-2/FED-1/RSD-4 is a transmembrane protein located in the lumenal membrane of the intestine; RSD-2 and RSD-6 form a protein complex that may bind RNA; and RSD-3 may mediate endocytosis. The silencing signal derived from in vivo expression of dsRNA or injection of dsRNA into a single gut cell is also presumably exported into the pseudocoelom from which it is imported into cells as above (not shown). 
a

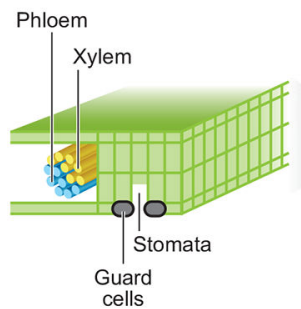

b Cell-to-cell transport

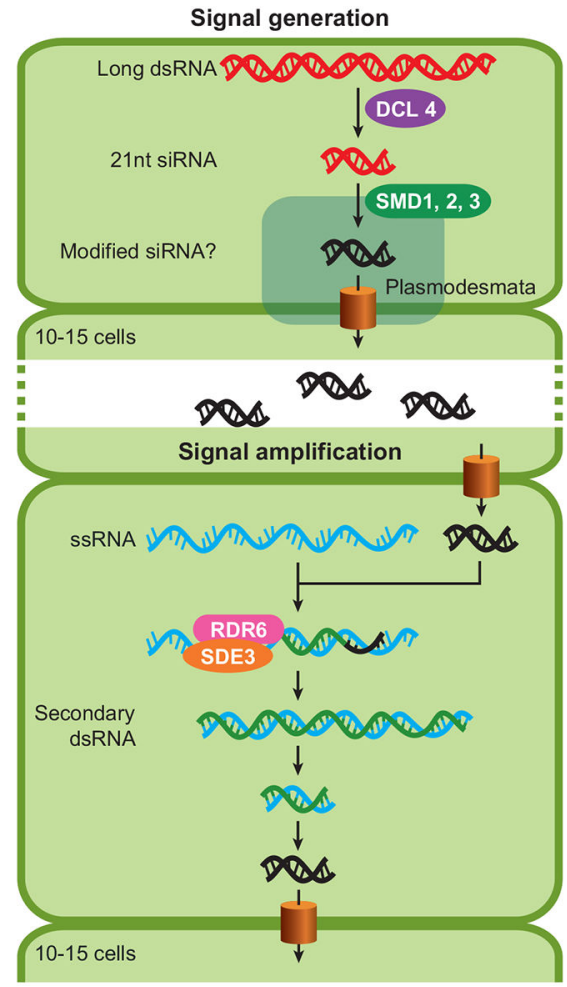

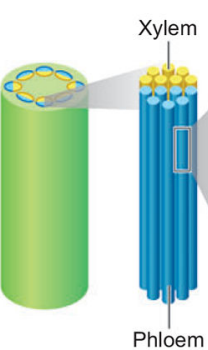

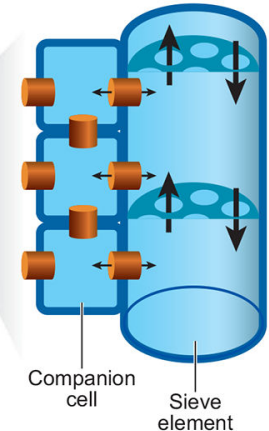

C Long-distance transport

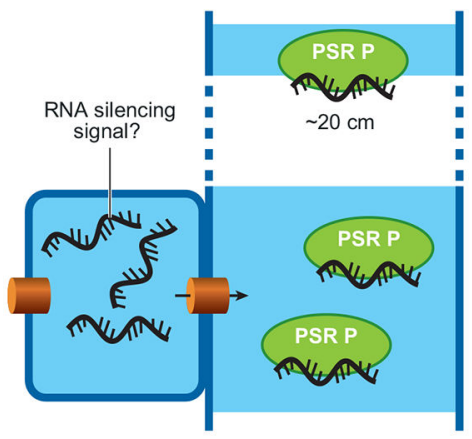

Figure 3.

Plants use distinct mechanisms for cell-to-cell and long-distance transport of silencing information. (a) Schematic showing the organization of plant vasculature. Long-distance transport of silencing information occurs through the phloem, comprised of companion cells that support associated sieve elements. Cell-to-cell transport in leaves occurs through plasmodesmal connections, which connect the cytoplasm of all cells except guard cells that surround sites of gaseous exchange (stomata). (b) Model for the generation and amplification of a cell-to-cell silencing signal. The RNAi trigger, long dsRNA, is converted to 21-nt siRNAs by DCL4, and modification of these 21-nt siRNAs for transport and/or their transport through plasmodesmata is controlled by the silencing movement defective genes (SMD1, 2, 3). This signal can travel for $~ 10-15$ cells without any amplification. However, in the presence of target mRNA, a cellular RNA-dependent RNA polymerase (RDR6) and an RNA helicase (SDE3) can direct the synthesis of secondary dsRNA, which may then be 
processed just as the trigger long dsRNA. (c) Model for the long-distance transport of a silencing signal. The silencing signal (likely RNA) may be transported as single-stranded short RNAs through the phloem since the phloem small RNA-binding protein 1 (PSRP1) of pumpkin specifically binds short single-stranded RNAs. Similar PSRPs may exist in other plants. 


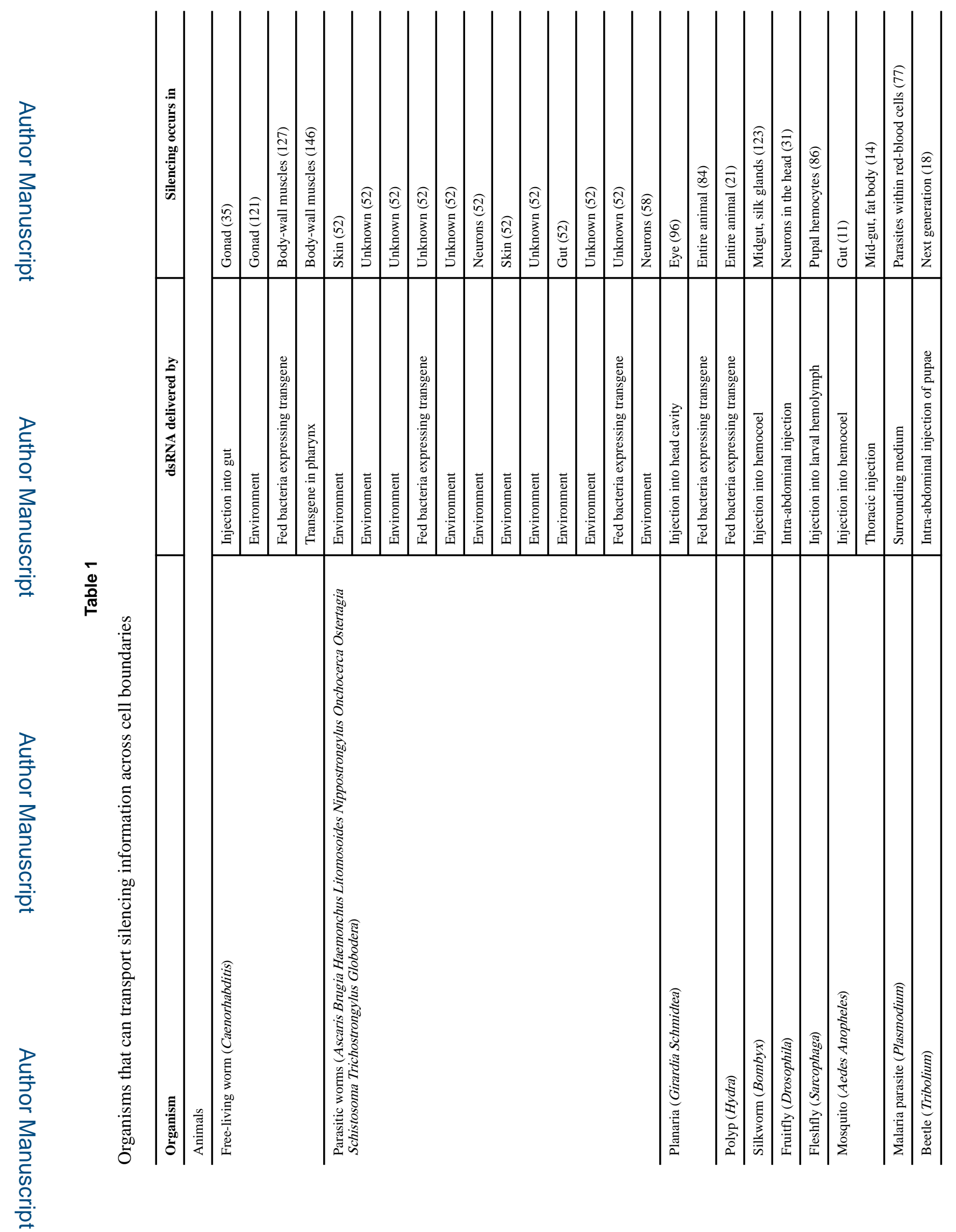

Annu Rev Genet. Author manuscript; available in PMC 2020 July 23. 


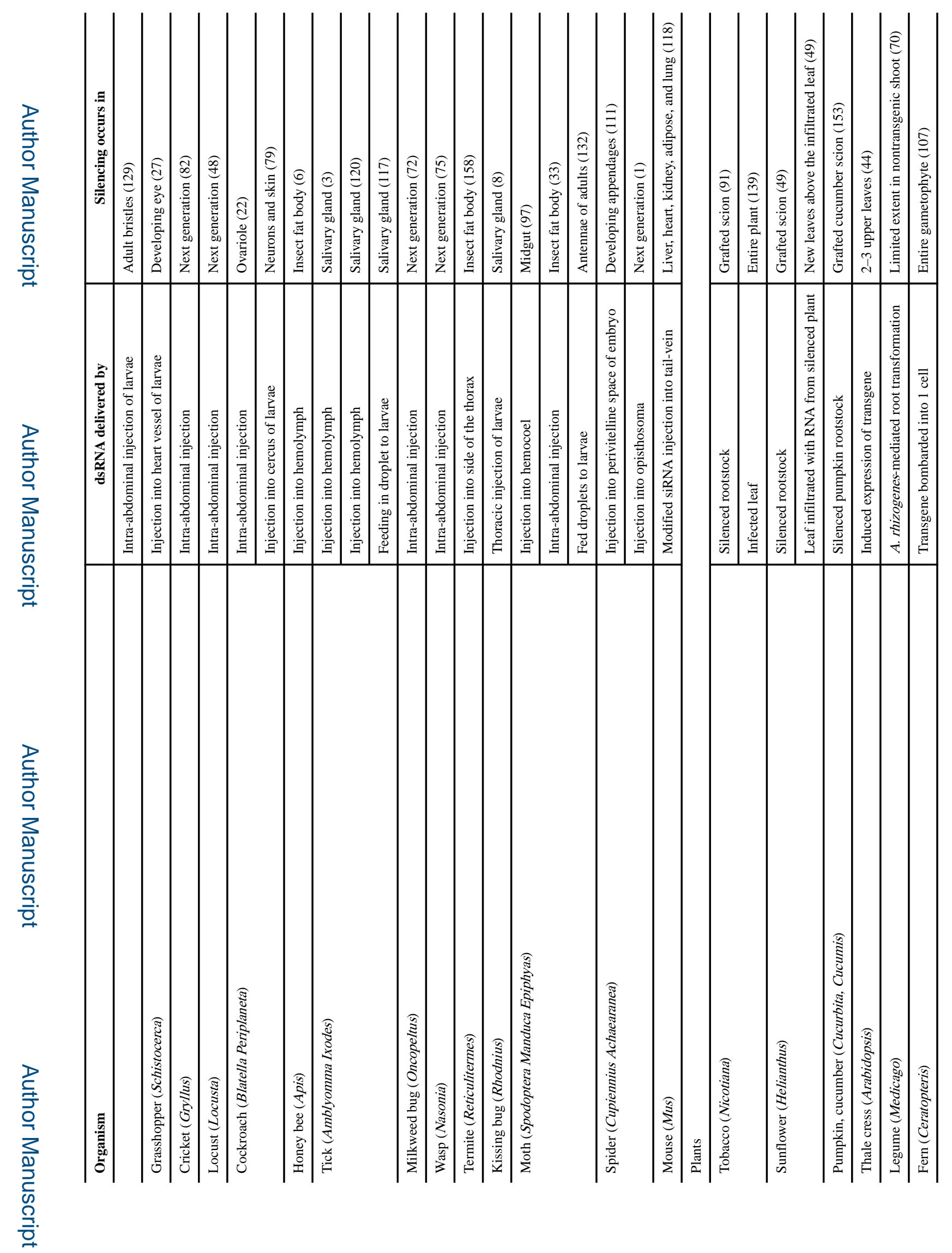

Annu Rev Genet. Author manuscript; available in PMC 2020 July 23. 